\title{
Deflection of a Main Crack along a Weak Plane Consisting of a Group of Preexisting Cracks in a Silicon Nitride Ceramic
}

\author{
Mamoru NAKAMURA, Ichinori SHIGEMATSU, Mamoru MABUCHI, Yasuo YAMADA, \\ Koji SHIMOJIMA, Naobumi SAITO and Masaru NAKANISHI \\ Department of Materials Processing, National Industrial Research Institute of Nagoya, 1-1, Hirate-cho, Kita-ku, Nagoya-shi \\ 窒化ケイ素セラミックス中の潜在亀裂群からなる弱い面に沿つた主亀裂の偏向

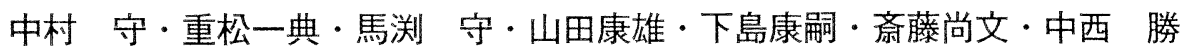 \\ 名古屋工業技術研究所材料プロセス部, 462 名古屋市北区平手町 1-1
} 462

\begin{abstract}
Deflection of a main crack along an artificially formed weak plane consisting of a group of preexisting cracks in a sillicon nitride ceramic, was studied experimentally. The weak planes inside the ceramics were formed by diffusion joining of the ceramics. Main cracks were produced by indentation. Deflection of a main crack was related to the strength of a joining interface. A weak joining interface could cause deflection of a main crack, and strengthen a specimen with an initial main crack. A main crack passed across a strong interface and caused catastrophic failure.

[Received June 9, 1997; Accepted August 7, 1997]
\end{abstract}

Key-words : Deflection of crack, Weak plane, Preexisting cracks, Silicon nitride, Diffusion joining, Joining defect, Joining strength

Toughness of a ceramic is strongly influenced by weak interfaces, such as grain boundaries and fiber/matrix interfaces. Cracking along those weak planes is an essential factor of toughening mechanism for ceramics. Many studies on cracking along weak planes caused by main cracks have been conducted on the basis of fracture mechanics. ${ }^{1)}$ However, the influence of a weak plane consisting of a group of small preexisting cracks on propagation of a main crack has not been studied yet. ${ }^{2)}$

In this paper, deflection of a crack along an artificially formed weak plane consisting of a group of joining defects, namely preexisting cracks, was studied experimentally. Weak planes were formed inside silicon nitride ceramics by diffusion joining. Mechanical properties of an interface formed by diffusion joining are influenced by size and distribution of joining defects. Due to those defects as preexisting cracks, it is difficult to apply the fracture mechanics to an analysis on deflection of the main crack along the weak interface. In this paper, the relationship between the strength of the joining interfaces and crack deflection behavior was examined.

Silicon nitride ceramics sintered with 3 mass $\% \mathrm{Al}_{2} \mathrm{O}_{3}$ and 5 mass $\% \quad \mathrm{Y}_{2} \mathrm{O}_{3}$ as additives, were used for experiments. Joining was carried out at $1773 \mathrm{~K}$ or $1873 \mathrm{~K}$ by hot pressing in $0.1 \mathrm{MPa}$ atm nitrogen atmosphere. Holding time at the joining temperatures was $1 \mathrm{~h}$.

To evaluate the joining strength with four-point bending test, specimens of size $3 \mathrm{~mm} \times 4 \mathrm{~mm} \times 40 \mathrm{~mm}$ were prepared from some ceramic joints made of two blocks of size $15 \mathrm{~mm} \times 15 \mathrm{~mm} \times 20 \mathrm{~mm} .{ }^{3)}$ For bending test, inner and outer spans were $10 \mathrm{~mm}$ and $30 \mathrm{~mm}$, respectively. Cross head speed was $0.5 \mathrm{~mm} / \mathrm{min}$. Table 1 shows the joining strength of the specimens fabricated with various joining conditions. The strength could be controlled by joining conditions of joining pressures, joining temperatures and finishing of surfaces to be joined. Small cracks at the interface of low joining strength are shown in Fig. 1. At an interface of high joining strength, average size of apparent joining defects was small.

Deflection of a crack along a weak plane was examined by bending test under above-mentioned conditions.
Table 1. Joining Strength of Specimens Formed with Various Joining Conditions

\begin{tabular}{|c|c|c|l|c|}
\hline Type & $\begin{array}{l}\text { Joining } \\
\text { temperature } \\
(\mathrm{K})\end{array}$ & $\begin{array}{c}\text { Joining } \\
\text { pressure } \\
(\mathrm{MPa})\end{array}$ & Surfaces to be joined & $\begin{array}{c}\text { Mean joining } \\
\text { strength } \\
\text { (MPa) }\end{array}$ \\
\hline 1 & 1773 & 16 & Ground / Ground & 75 \\
2 & 1873 & 22 & Ground / Ground & 128 \\
3 & 1873 & 22 & Ground / Mirror finished & 197 \\
4 & 1873 & 22 & Mirror finished/Mirror finished & 642 \\
\hline
\end{tabular}

Flexural strength of original body was $1 \mathrm{GPa}$ on average.

Ground: Surfaces were finished by grinding with a \#400 diamond wheel.

Mirror finished: Surfaces were mirror finished by polishing with $1 \mu \mathrm{m}$ dia. powder. Ground/Mirror finished: Surfaces of narrow and thin plates were ground, and

surfaces of bending bars were mirror finished.

Specimens were prepared with procedures shown in Fig. 2. A narrow and thin ceramic plate $(0.7 \mathrm{~mm} \times 4 \mathrm{~mm} \times 40 \mathrm{~mm})$ was joined to each bending bar $(3 \mathrm{~mm} \times 4 \mathrm{~mm} \times 40 \mathrm{~mm})$. Large surface cracks were produced by indentation with Vickers diamond pyramids. The indentation load was $98 \mathrm{~N}$ (length of the surface cracks: $2 a$ was about $0.24 \mathrm{~mm}$ ) or $480 \mathrm{~N}$ ( $2 a$ was about $0.7 \mathrm{~mm}$ ). The surface cracks were perpendicular to the joining interfaces.

A typical load-displacement curve during bending test of a specimen of low joining strength is shown in Fig. 3. After attaining to the low first peak (point: B in Fig. 3), the load dropped sharply (point: $\mathrm{C}$ ), and then rose steadily to the high final peak (point: D). The specimen after the failure is shown in Fig. 4(a). They mean as follows. The large main crack has started unstable propagation at point: $B$, connected with preexisting cracks at the joining interface and been deflected (point: C). The drop of the load (from point: $\mathrm{B}$ to point: C) was caused by change of the compliance of the specimen with the propagation of the main crack and cracking along the joining interface.

Relationships between the flexural strength of specimens and joining strength are shown in Fig. 5. If failure occurred after debonding at the interfaces, the flexural strength in 

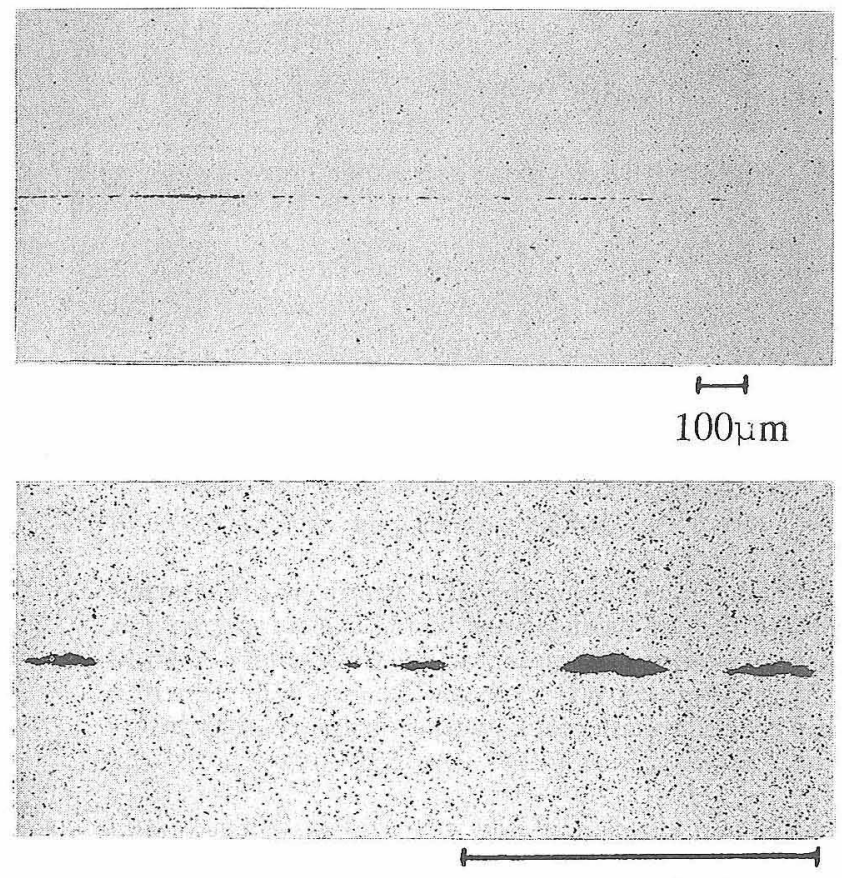

$100 \mu \mathrm{m}$

Fig. 1. Cracks formed at a joining interface by diffusion joining. Joining pressure: $16 \mathrm{MPa}$, Joining temperature: $1773 \mathrm{~K}$, Surfaces to be joined: ground by a $\$ 400$ diamond wheel (surface roughness: $1 \mu \mathrm{m})$

(a) Bending bar and narrow and thin plate to be joined

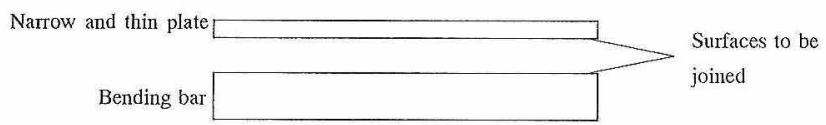

\section{(b) Diffusion joining}

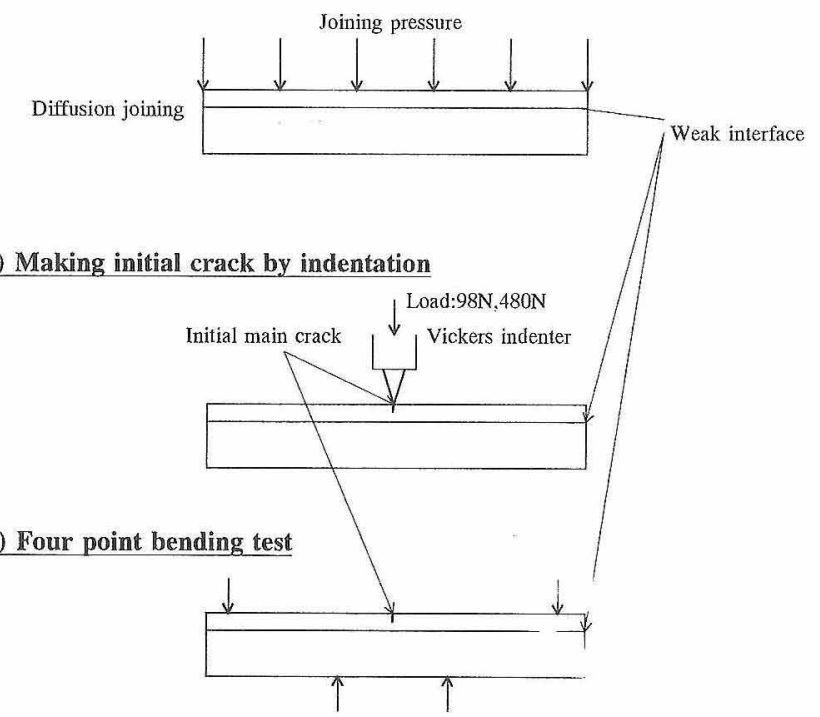

Fig. 2. Procedures for preparation of specimens and bending test.

the figure indicated the maximum tensile stress appeared at the surface of the original bars of size $3 \mathrm{~mm} \times 4 \mathrm{~mm} \times 40$ $\mathrm{mm}$. The flexural strength of the specimens of low joining strength, which broke after debonding, was not much lower

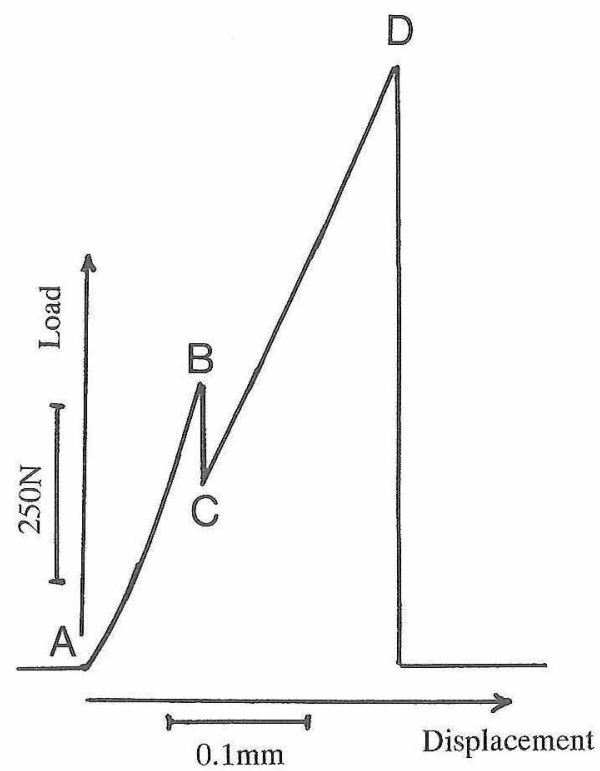

Fig. 3. Load-displacement curve during bending test of a specimen with a weak joining interface. Joining pressure: $16 \mathrm{MPa}$, Joining temperature: $1773 \mathrm{~K}$, Surfaces to be joined: ground by a $\$ 400$ diamond wheel (surface roughness: $1 \mu \mathrm{m})$

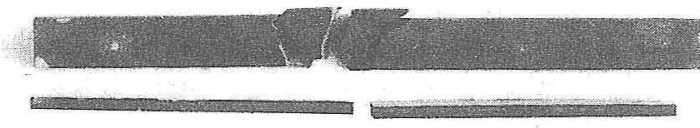

(a)

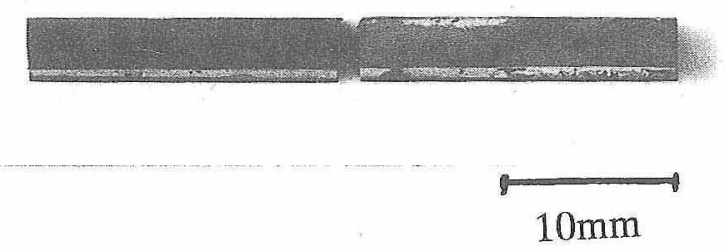

(b)

Fig. 4. Specimens after failure.

(a) Specimen with a weak interface (Joining type: 1 in Table 1, Mean joining strength: $75 \mathrm{MPa}$, Indented with load of $98 \mathrm{~N}$, (b) Specimen with a strong interface (Joining type: 3 in Table 1, Mean joining strength: $197 \mathrm{MPa}$, Indented with load of $98 \mathrm{~N}$ ).

than the strength of the original body. The main cracks were deflected along the weak joining interfaces. Furthermore, the surfaces formed by debonding were not damaged seriously.

On the other hand, the indented specimens of high joining strength showed low flexural strength, because the main cracks were not deflected along the joining interfaces and passed across those interfaces (Fig. 4(b)). 


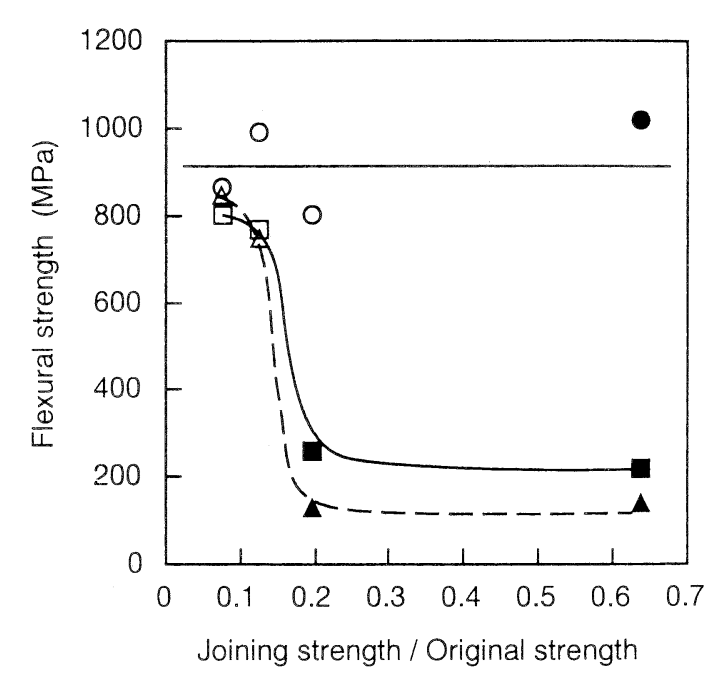

Fig. 5. Relationships between flexural strength of specimens and joining strength.

$\bigcirc$ Without indent, $\square$ Indented with load of $98 \mathrm{~N}, \triangle \mathbf{\Delta}$ Indented with load of $490 \mathrm{~N}$, ODA Failure without debonding, $\bigcirc$ Failure with debonding at joining interfaces. (Failure of specimens occurred with debonding concurrently), $\square \Delta$ Failure following debonding at joining interfaces.

It is inferred as follows. Just before the tips of the main cracks arrived at weak joining interfaces, large tensile stress parallel to the propagation direction of the main cracks had been caused by stress concentration near the tips of the cracks. The preexisting cracks near the tips had started extending and coalescing under the tensile stress. Most of the fronts of the main cracks would have met the preexisting cracks at the joining interfaces, and then the deflection of the main cracks along the weak planes would have occurred (Cook-Gordon's mechanism ${ }^{4)}$ ). The stren- gth of the joining interfaces can be related to the extension of preexisting cracks.

If the preexisting cracks had not extended before the main cracks arrived at the interfaces, some parts of the crack fronts would have passed across the interfaces without meeting the preexisting cracks. In such cases, those main cracks would have caused failure of the specimens or serious degradation of the flexural strength.

The fracture toughness related to the tensile stress distribution near the crack tip is intrinsic fracture toughness. Ordinary fracture toughness of a ceramic is much higher than intrinsic one due to stress shielding mechanisms. Furthermore, a frontal process zone of a crack tip modifies the stress distribution calculated on the basis of the linear fracture mechanics. Actually, the maximum tensile stress appears near a crack tip must be lower than ideal strength of a silicon nitride crystal. Nevertheless high intrinsic fracture toughness of a ceramic as well as low strength of a weak plane would tend to cause the deflection of a crack along the weak interface.

In a case of a ceramic component for practical use, lower limit of strength, direction and location of a weak plane must be determined in consideration of stress distribution, which appears in the component in operation.

(This work was promoted by AIST, MITI, Japan as part of the Synergy Ceramics Project under the Industrial Science and Technology Frontier (ISTF) Program)

\section{References}

1) A. G. Evans, J. Am. Ceram. Soc., 73, 187-206 (1990).

2) M. Nakamura and I. Shigematsu, Proceedings of 1996 Annual Meeting of Ceram. Soc. Japan, Yokohama (1996) p. 552.

3) M. Nakamura, K. Kubo, S. Kanzaki and H. Tabata, J. Mater. Sci., 22, 1259-64 (1987).

4) J. Cook and J. E. Gordon, Proc. Roy. Soc., London, A282 (1964) pp. 508-20. 